\title{
EGFR NM_005228.3:c.2232_2233ins18
}

National Cancer Institute

\section{Source}

National Cancer Institute. EGFR NM 005228.3:C.2232 2233ins18. NCI Thesaurus. Code C98596.

An insertion of 18 nucleotides, AAAAT TCCCGT CGCTATC, between position 2232 and 2233 of the coding sequence of the EGFR gene. 